\title{
Stochastic modeling using Markov chain on the forecast standardized precipitation index
}

\section{Modelagem estocástica utilizando cadeia de Markov na previsão do índice padronizado de precipitação}

\section{Claudia Fernanda Almeida TEIXEIRA-GANDRA ${ }^{1}$; Rita de Cássia Fraga DAMÉ²; Gisele Machado da SILVA ${ }^{3}$}

\begin{abstract}
${ }^{1}$ Corresponding author; Agricultural Engineer, Doctor Science, Associate Professor II; Universidade Federal de Pelotas (UFPel), Center for Engineering, Pelotas, Rio Grande do Sul, Brasil; cfteixei@ig.com.br

${ }^{2}$ Agricultural Engineer, Doctor Science, Associate Professor IV; Universidade Federal de Pelotas (UFPel), Center for Engineering, Pelotas, Rio Grande do Sul, Brasil; ritah2o@hotmail.com

${ }^{3}$ Master/PhD, Program in Management and Conservation of Soil and Water (MACSA); University of Pelotas, Rio Grande do Sul, Brasil; giselesilva@cavg.ifsul.edu.br
\end{abstract}

Recebido em: 04-08-2016; Aceito em: 15-12-2016

\begin{abstract}
Grain production and livestock are the basis of the state of Rio Grande do Sul/Brazil economy and favorable rainfall conditions accounts for about $20 \%$ of Brazilian production. However, the state has faced periods of drought, especially in the campaign area, decisively affecting agricultural production and hence the economy. The objective of this paper is to predict the Standardized Precipitation Index (SPI) on a monthly scale, from a series of rainfall from 1991 to 2012, for the city of Bagé/RS/Brazil, in order to extend it by over 22 years, using a Markov chain to simulate the occurrence of rainfall and the Gamma distribution for predicting the precipitated amount. The results showed that the model simulated two-state Markov sequences of dry and wet days, keeping the statistical characteristics of the series. There were underestimations of the number on events classified as extreme and severe drought, obtained by serial SPI simulated compared to observed ones.
\end{abstract}

Additional keywords: climate anomaly; drought index; SPI.

\section{Resumo}

A produção de grãos e a pecuária constituem a base da economia do Estado do Rio Grande do Sul/Brasil, e em condições pluviais favoráveis produz cerca de $20 \%$ da produção. No entanto, o estado tem enfrentado períodos de estiagem, especialmente na região da campanha, afetando de forma decisiva a produção agrícola e, consequentemente, a economia. Assim, objetivou-se prever o comportamento do Índice Padronizado de Precipitação (SPI) em escala mensal, a partir de uma série de precipitações pluviais de 1991 a 2012, para o município de Bagé/RS/Brasil, de forma a estendê-la por mais 22 anos, utilizando a cadeia de Markov para a simulação da ocorrência da precipitação e a distribuição Gama para a predição da quantidade precipitada. Os resultados obtidos permitiram concluir que o modelo de Markov de dois estados simulou as sequências de dias secos e chuvosos, mantendo as características estatísticas das séries. Houve subestimativa no número de eventos classificados como seca extrema e severa, obtidos mediante a série de SPI simulada, comparativamente à observada.

Palavras-chave adicionais: anomalia climática; índice de seca; SPI.

\section{Introduction}

The state of Rio Grande do Sul/Brazil is a major producer of grain, soybeans and corn being the two main rainfed crops, accounting for over $70 \%$ of the cultivated state area (Berlato \& Cordeiro, 2005). Are conducted virtually no irrigation and their income is dependent on weather conditions and rainfalls. According to Azevedo \& Leitão (1990), factors such as declining water availability for crops exacerbate the effects of drought, resulting in agricultural production decrease. Under these circumstances, any reduction in annual rainfall or occurrence of "dry spells" - characterized by the occurrence of dry periods within the rainy season - throughout the growing season may lead to the total or partial loss of agricultural production.

This fact inspires several studies in attempt to characterize the spatial and temporal precipitation behavior in order to analyze the occurrence of drought periods, and establish technical recommendations, which are useful to farmers (Andrade et al., 2008; Carvalho et al., 2013).

The analysis of time series of hydrological variables allows you to check their previous behavior, and thus adjust the parameters of a suitable prediction of the same mathematical model (Salas et al., 1980; Cargnelutti Filho et al., 2010).

The stochastic modeling, which considers the randomness of the variable analyzed using Markov chains, was initially developed by Stern \& Coe (1984), 
referring to the simulation of sequences of dry and wet days, whose parameters are the transition probabilities of states, derived from the historical sequence of daily rainfall. After a simulated time sequence of dry and wet days, a theoretical probability model is used, as the Gamma distribution, Exponential or Pearson III, to know the amount precipitated in rainy day (Araújo et al., 2012). Thus, it is possible to predict the occurrence of dry periods, with the daily amount of rain and, therefore, the monthly total of a series using a Markov chain and a probabilistic model that enable the generation of synthetic series (Mehrotra et al., 2006). Thus, considering the observed data ( $\mathrm{N}$ years) and those obtained by the stochastic process mentioned ( $M$ years), we obtain a mixed series ( $\mathrm{N}+\mathrm{M}$ years), which allows the knowledge of future events.

There are several indicators developed to quantify, standardize and compare the drought in temporal and spatial as a basis, as the Severity Index Palmer Drought (PDSI), the Severity Index Palmer Modified Drought or the Standardized Precipitation Index (SPI), among others. The SPI, initially developed by Mckee et al. (1993), quantifies the deficit or excess of rainfall at different time scales, a feature which makes this index a valuable method for all studies of water availability, whether short or long term (Hayes et al., 1999). According Sansigolo (2004), physically, the SPI for a given period of time is the difference between the observed precipitation and the mean divided by the standard deviation. In order to compare time series of PDSI with SPI using spectral analysis, the nominated author has used rainfall data from Piracicaba/SP/Brazil, in the period from 1917 to 2001 . During the period considered were defined by PDSI 6 moderate drought events 1 and end with durations between 7 and 23 months and at six-month SPI, 6 were moderate drought events 1 and end with durations between 6 and 17 months.

Blain et al. (2010) has verified the use of SPI in monitoring of deficiencies and excess rainfall in monthly scale, in the state of Espírito Santo/Brazil. The authors concluded, through the analysis of autocorrelation and cross-correlation, the main feature of the SPI series is its large spatial and temporal variability, which indicates that in the same region extremely dry months may be preceded and/or followed by months wet or normal months, and that different cases of drought can occur randomly between locations and in the same period.

In this context, the objective was to predict the standardized precipitation index, from a series of rainfall from 1991 to 2012, for the city of Bagé/RS/Brazil, in order to extend it by another 22 years, using the Markov chain of two states for simulation.

\section{Material and methods}

Were used daily rainfall data of Bagé, located at coordinates $31^{\circ} 20^{\prime} \mathrm{S}$ and $54^{\circ} 06^{\prime} \mathrm{W}$ and altitude of $242.31 \mathrm{~m}$, belonging to the National Institute of Meteorology (INMET) in the period 1991-2012.

To modeling the rainfall through the Markov chain of two states, ie, the probability of a dry or rainy day is dependent only on the condition of the previous day, the day being considered dry (0) or rainy (1) (Stern \& Coe, 1984). It was considered dry day one whose daily rainfall was less than or equal to $1 \mathrm{~mm}$ (Dereczynski et al., 2009).

Equations (1), (2), (3) and (4) were used to determine the transition probability matrix, P00, P10, P01 e P11:

$$
\begin{aligned}
& \mathrm{POO}_{\mathrm{i}}=\frac{\mathrm{NOO}_{\mathrm{i}}}{\mathrm{NOO}_{\mathrm{i}}+\mathrm{NO1}_{\mathrm{i}}} \\
& \mathrm{P} 10_{\mathrm{i}}=\frac{\mathrm{N} 10_{\mathrm{i}}}{\mathrm{N} 10_{\mathrm{i}}+\mathrm{N} 11_{\mathrm{i}}} \\
& \mathrm{PO1}_{\mathrm{i}}=1-\mathrm{P00} \\
& P 11_{i}=1-P 10 i
\end{aligned}
$$

where P00 is the likelihood for a dry day, being that the previous one was also dry; P10 is the likelihood for a dry day, being that the previous one was wet; P01 is the likelihood for a wet day, being that the previous one was dry; P11 is the likelihood for a wet day, being that the previous one was also wet; $\mathrm{N} 10$ is the observed frequency for a sequence of a wet day followed by a dry day; N11 is the observed frequency for a sequence of a wet days; N00 is the observed frequency for a sequence of a dry days; N01 is the observed frequency for a dry day followed by a wet day, and $i$ is the year.

After being estimated the transition probabilities, 100 sequences of dry/rainy days over the entire study period were generated. From the sequences generated for each period, the precipitated amounts were determined on days considered rainy.

The amount of rain was estimated by two Gamma distribution parameters (Detzel \& Mine, 2011), and the cumulative probability function:

$F(X)=P(X \leq x)=\frac{1}{\Gamma(\gamma) \beta^{\gamma}} \int_{0}^{x} X^{\gamma-1} e^{-\frac{X}{\beta}} d x$

where $\beta$ and $\gamma$ are the distribution parameters, estimated through the momentum method (equations 6 and 7), and $\Gamma(\gamma)$ is the Gamma function.

$\beta=\frac{s^{2}}{\bar{x}}$
$\gamma=\frac{\bar{x}^{2}}{s^{2}}$

where $\bar{x}$ is the observed mean for days with precipitation $(\mathrm{mm})$, and $\mathrm{s}^{2}$ is the observed variance.

Once the Gamma function is indeterminate for $x=0$ and there is a distribution of precipitation containing zeros, the cumulative probability takes the following form (equation 8).

$H(x)=q+(1-q) G(x)$

where $H(x)$ is the cumulative probability distribution, $q$ 
is the probability of nulls (zeros), Thom (1966) indicates that $q$ can be estimated by $m /(n+1)$, $m$ is the number of zeros in a time series of precipitation, and $G(x)$ is the theoretical cumulative distribution.

To verify homoscedasticity on variances of the mean values and standard of observed and simulated series, for a $5 \%$ level of probability deviation statistics, we applied the t-test for paired samples (Blain et al., 2009).

The cumulative probability distribution $\mathrm{H}(\mathrm{x})$ is transformed into a normalized random variable $(Z)$, with mean zero and standard deviation 1 , where the variable $(Z)$ is the value of SPI. The value (Z) or SPI can be obtained by a mathematical approach developed by Abramowitz \& Stegun (1965), which converts the cumulative distribution on a normal probability variable (Z). Where in $Z$ is defined by equations (9) and (10):

$\mathrm{Z}=\mathrm{SPI}=-\left(\mathrm{t}-\frac{\mathrm{C}_{0}+\mathrm{C}_{1} \mathrm{t}^{+} \mathrm{C}_{2} t^{2}}{1+\mathrm{d}_{1} \mathrm{~d}^{2} \mathrm{~d}_{2} \mathrm{t}^{2}+\mathrm{d}_{3} \mathrm{t}^{3}}\right)$ for $0<\mathrm{H}(\mathrm{x}) \leq 0.5$

$\mathrm{Z}=\mathrm{SPI}=+\left(\mathrm{t}-\frac{\mathrm{C}_{0}+\mathrm{C}_{1} \mathrm{t}^{+} \mathrm{C}_{2} \mathrm{t}^{2}}{1+\mathrm{d}_{1} \mathrm{t} \mathrm{d}_{2} \mathrm{t}^{2}+\mathrm{d}_{3} \mathrm{t}^{3}}\right)$ for $0.5<\mathrm{H}(\mathrm{x}) \leq 1.0$

$\mathrm{t}$ being defined by equations 11 and 12 .

$t=\sqrt{\ln \left[\frac{1}{(H(x))^{2}}\right]} \quad$ for $0<H(x) \leq 0.5$

$\mathrm{t}=\sqrt{\ln \left[\frac{1}{(1-\mathrm{H}(\mathrm{x}))^{2}}\right]} \quad$ for $0.5<\mathrm{H}(\mathrm{x})<1.0$

The coefficients used in equations (9) and (10) are: $C_{0}=2.515517 ; C_{1}=0.802853 ; C_{3}=0.010328 ; d_{1}=$ $1.432788 ; d_{2}=0.189269 ; d_{3}=0.001308$.

After determination of the SPI values to monthly ranking, classification of scale values was used as the severity of the drought, according to Fernandes et al. (2010) (Table 1).

Table1 - Classification of the strength of the drought according to the Standardized Precipitation Index (Fernandes et al., 2010).

\begin{tabular}{cl}
\hline $\begin{array}{c}\text { Standardized Precipitation } \\
\text { Index (SPI) } \\
\text { (dimensionless) }\end{array}$ & Class of severity \\
\hline 0.49 a -0.49 & Normal \\
-0.50 a -0.99 & Mild drought \\
-1.00 a -1.49 & Moderate drought \\
-1.50 a -1.99 & Severe drought \\
$\leq-2.00$ & Extreme drought \\
\hline
\end{tabular}

To check the adjustment of the rainfall probability distribution Gamma series, prior to application of the SPI, the graph plotting position was used as well as the adherence tests Chi-square and KolmogorovSmirnov tests, at a significance level of $5 \%$ (Wilks, 2006).

\section{Results and discussions}

It is found that the average monthly values of the simulated probability P00 series features for the historical series, a maximum variation of $10.97 \%$, which shows the adequate representation of the dry period by homogeneous Markov chain of two states (Table 2).

Yet considering that the soybean crop in the state of Rio Grande do Sul has its cultivation over the months from October to March (Berlato \& Cordeiro, 2005), and also the difference between the averages of transition probability P00 series observed and simulated in the period is $9.30 \%$, confirming the suitability of the model, showing that stochastic modeling based on Markov chain is a tool that can be applied in studies related to drought, in climate zoning purposes.

It is noteworthy that there was no abrupt change between the odds throughout the year, indicating that the use of monthly mean values will not result in significant errors in the simulations. Breinl et al. (2013) applied a model of daily precipitation based on the Markov chain, using as its validation, among other statistical parameters, the transition probabilities of states. The authors found that the results of $\mathrm{POO}$, in general, were satisfactory and can be used in the simulation of events, corroborating the results of this work. The values of the transition probability, P01, were lower for the series of simulated rainfall, with the highlight for the month of July with a maximum variation of $24.98 \%$.

The differences between the transition probabilities of the observed and simulated series where the largest deviations occurred with the P01 and P10 probabilities in the months of May and July (Figure 1). During this period, in the state of Rio Grande do Sul, winter pastures as feed for cattle supplementation are grown, as is usual the use of native pasture and feed. Thus, a maximum variation of $24.98 \%$ in just two months, does not imply larger errors in the results of the process simulation series.

The values of the shape parameters $(\alpha)$ and scale $(\beta)$ of the Gamma distribution used to obtain the precipitated daily depth as well as the result of chisquare $\left(\chi^{2}\right)$ adherence and Kolmogorov-Smirnov (KS) test, at a $5 \%$ probability of error significance level, are shown in Table 3. Observe that both these tests show that the Gamma distribution is suitable to perform the prediction of daily amount of rain, whereas the calculated statistics were always lower the critical level of probability set. According to Andrade Júnior et al. (2001), who used the distribution functions of probabilities and empirical range to simulate daily rainfall for regions of Parnaíba and Teresina, $\mathrm{Pl} / \mathrm{Brazil}$, through process of simulation based on the Monte Carlo method, the best fit occurred Parnaíba data when using the Gamma distribution. In Teresina, contrary to expectations, there was not a good fit of data to the function of Gamma distribution for the period by the rainy season. 
Table 2 - Transition probabilities P00, P01, P11 and P10 of the rainfall series observed and simulated for Bagé/RS/Brazil.

\begin{tabular}{ccccccccc}
\hline \multirow{2}{*}{ Month } & \multicolumn{3}{c}{ Observed series } \\
\cline { 2 - 8 } & ${ }^{1} \mathrm{P} 00$ & ${ }^{2} \mathrm{P} 01$ & ${ }^{3} \mathrm{P} 11$ & ${ }^{4} \mathrm{P} 10$ & $\mathrm{P} 00$ & $\mathrm{P} 01$ & $\mathrm{P} 11$ & $\mathrm{P} 10$ \\
\hline Jan & 0.772 & 0.626 & 0.374 & 0.229 & 0.733 & 0.727 & 0.273 & 0.268 \\
Feb & 0.751 & 0.448 & 0.552 & 0.249 & 0.641 & 0.641 & 0.359 & 0.359 \\
Mar & 0.783 & 0.510 & 0.490 & 0.217 & 0.700 & 0.707 & 0.293 & 0.300 \\
Apr & 0.786 & 0.505 & 0.495 & 0.213 & 0.702 & 0.700 & 0.300 & 0.298 \\
May & 0.814 & 0.472 & 0.529 & 0.187 & 0.712 & 0.721 & 0.279 & 0.289 \\
Jun & 0.761 & 0.444 & 0.556 & 0.239 & 0.647 & 0.653 & 0.347 & 0.353 \\
Jul & 0.793 & 0.440 & 0.560 & 0.207 & 0.681 & 0.681 & 0.319 & 0.319 \\
Aug & 0.772 & 0.519 & 0.481 & 0.228 & 0.693 & 0.691 & 0.309 & 0.307 \\
Sep & 0.760 & 0.469 & 0.532 & 0.240 & 0.661 & 0.668 & 0.333 & 0.339 \\
Oct & 0.748 & 0.513 & 0.487 & 0.252 & 0.674 & 0.673 & 0.327 & 0.326 \\
Nov & 0.801 & 0.546 & 0.455 & 0.199 & 0.731 & 0.733 & 0.267 & 0.269 \\
Dec & 0.783 & 0.572 & 0.428 & 0.217 & 0.726 & 0.726 & 0.274 & 0.274 \\
\hline Mean & 0.777 & 0.505 & 0.495 & 0.223 & 0.692 & 0.693 & 0.307 & 0.308 \\
\hline
\end{tabular}

${ }^{1} \mathrm{P} 00$ = Likelihood for a dry day, being that the previous one was also dry; ${ }^{2} \mathrm{P} 01$ = Likelihood for a wet day, being that the previous one was dry; ${ }^{3} \mathrm{P} 11=$ Likelihood for a wet day, being that the previous one was also wet; ${ }^{4} \mathrm{P} 10=\mathrm{Likelihood}$ for a dry day, being that the previous one was wet.

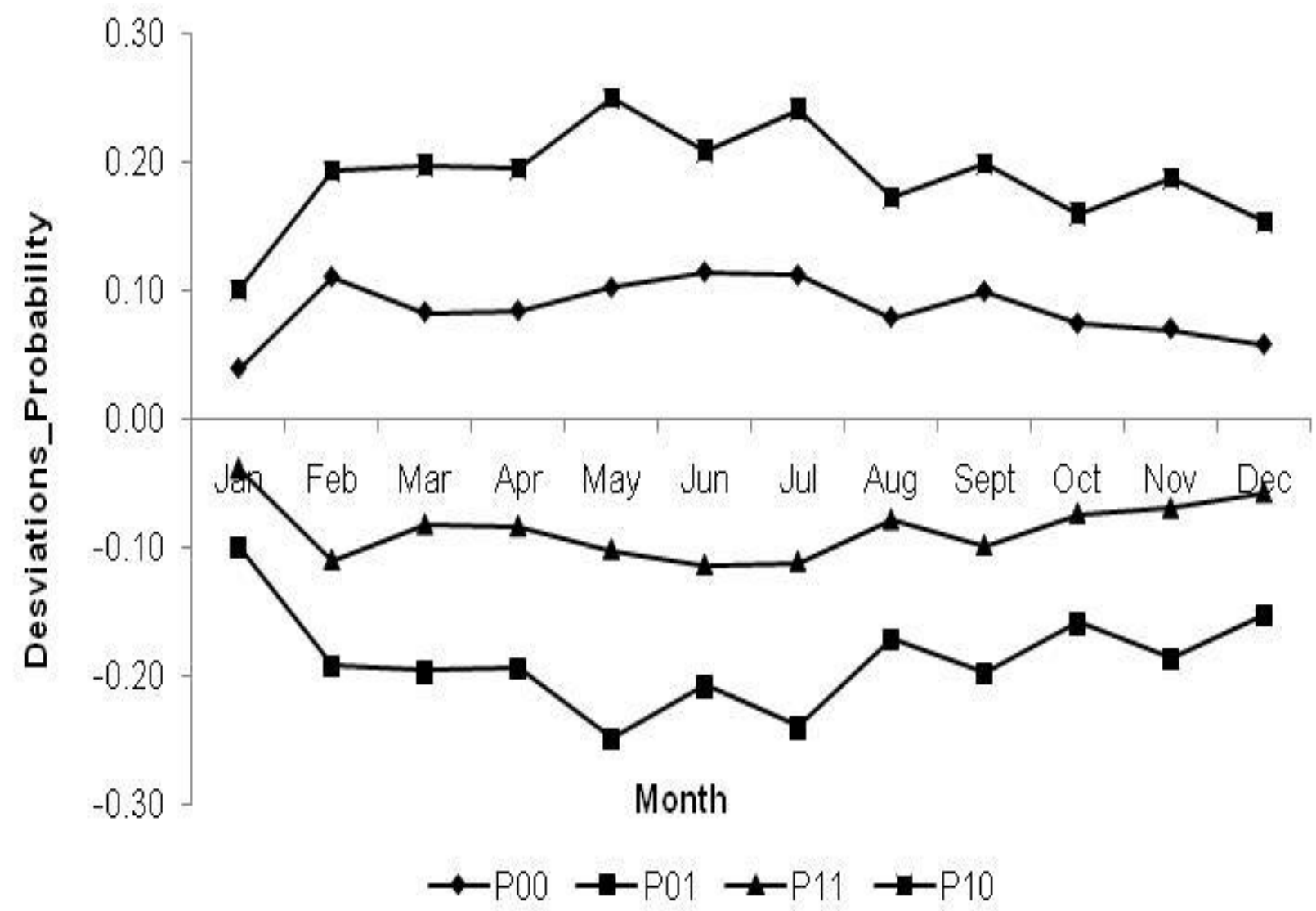

Figure 1 - Values of the deviations between the transition probabilities, P00 (likelihood for a dry day, being that the previous one was also dry), P01 (likelihood for a wet day, being that the previous one was dry), P11 (likelihood for a wet day, being that the previous one was also wet) and P10 (likelihood for a dry day, being that the previous one was wet), the precipitation observed and simulated series. 
Table 3 - Parameters form $(\alpha)$ and scale $(\beta)$ of Gamma distribution used to obtain the daily rainfall and the adherence tests applied to the location of Bagé/RS/Brazil.

\begin{tabular}{lccccc}
\hline \multirow{2}{*}{ Month } & \multicolumn{2}{c}{ Parameters of the distribution } & \multicolumn{3}{c}{ Tests } \\
\cline { 2 - 6 } & $\alpha$ & $\beta$ & ${ }^{1} \mathrm{KS}_{\text {cal }}$ & ${ }^{2} \mathrm{KS}_{\text {crit }}$ & ${ }^{3} \chi^{2}$ cal \\
\hline Jan & 0.48 & 28.38 & 0.12 & 0.59 & 5.27 \\
Feb & 0.47 & 28.51 & 0.28 & 0.62 & 3.64 \\
Mar & 0.70 & 16.98 & 0.14 & 0.66 & 2.00 \\
Apr & 0.43 & 44.97 & 0.14 & 0.69 & 3.64 \\
May & 0.67 & 22.09 & 0.14 & 0.65 & 3.09 \\
Jun & 0.51 & 23.70 & 0.12 & 0.56 & 3.64 \\
Jul & 0.58 & 22.33 & 0.16 & 0.79 & 2.55 \\
Aug & 0.57 & 20.20 & 0.12 & 0.59 & 5.27 \\
Sep & 0.62 & 17.30 & 0.14 & 0.66 & 4.73 \\
Oct & 0.61 & 23.39 & 0.09 & 0.46 & 0.36 \\
Nov & 0.61 & 24.78 & 0.15 & 0.75 & 4.73 \\
Dec & 0.62 & 23.30 & 0.12 & 0.56 & 5.27 \\
\hline
\end{tabular}

${ }^{1} \mathrm{KS}_{\text {cal }}=$ calculated statistic of the Kolmogorov-Smirnov test; ${ }^{2} \mathrm{KS}$ crit $=$ critical statistic of the Kolmogorov-Smirnov test; ${ }^{3} \chi^{2}$ cal calculated statistic of the Chi-Square test; $\chi^{2}$ crit $=11.59 ; \alpha=5 \%$.

It is observed that for the monthly average the coefficient of variation differs from $0.5 \%$ (July) to $11 \%$ (November) (Table 4). Also for November we found the biggest difference in the values of standard deviation $(15 \%)$. The average annual value of the coefficient of variation for both series was about $36 \%$. The small differences between the values of descriptive statistics suggest the adequacy of the simulation sequence of dry and wet days using a Markov chain.

Table 4 - Descriptive statistics of the monthly series of simulated and observed precipitation in Bagé/RS/Brazil.

\begin{tabular}{lcccccc}
\hline \multirow{3}{*}{ Month } & \multicolumn{3}{c}{ Observed series } & \multicolumn{3}{c}{ Simulated series } \\
\cline { 2 - 7 } & $\begin{array}{c}\text { Mean } \\
(\mathrm{mm})\end{array}$ & $\begin{array}{c}1 \mathrm{DP} \\
(\mathrm{mm})\end{array}$ & $\begin{array}{c}{ }^{2} \mathrm{CV} \\
(\%)\end{array}$ & $\begin{array}{c}\text { Mean } \\
(\mathrm{mm})\end{array}$ & $\begin{array}{c}\text { DP } \\
(\mathrm{mm})\end{array}$ & \begin{tabular}{c}
\multicolumn{1}{c}{$\mathrm{CV}$} \\
$(\%)$
\end{tabular} \\
\hline Jan & 3.83 & 12.26 & 31.27 & 3.63 & 11.58 & 31.44 \\
Feb & 4.84 & 13.40 & 36.11 & 4.81 & 13.21 & 36.40 \\
Mar & 3.79 & 9.73 & 38.98 & 3.66 & 9.65 & 37.93 \\
Apr & 6.49 & 19.91 & 32.63 & 5.87 & 18.33 & 32.15 \\
May & 4.61 & 12.59 & 36.66 & 4.16 & 11.53 & 36.19 \\
Jun & 4.34 & 11.80 & 36.80 & 4.30 & 11.53 & 37.39 \\
Jul & 4.09 & 11.60 & 35.26 & 4.11 & 11.17 & 36.88 \\
Aug & 3.23 & 9.38 & 34.45 & 3.42 & 9.65 & 35.48 \\
Sep & 3.44 & 9.09 & 37.89 & 3.63 & 9.34 & 38.91 \\
Oct & 4.86 & 12.40 & 39.24 & 4.64 & 12.21 & 38.07 \\
Nov & 3.53 & 10.09 & 35.00 & 3.93 & 11.59 & 33.94 \\
Dec & 4.06 & 11.92 & 34.09 & 3.98 & 11.56 & 34.56 \\
\hline
\end{tabular}

${ }^{1} \mathrm{DP}=$ standard deviation; ${ }^{2} \mathrm{CV}=$ coefficient of variation.

According to Damé et al. (2008) a stochastic model is appropriate to represent a time series if its statistical characteristics are preserved. The results of Student's t test (Blain et al., 2009) for observed and simulated mean and standard deviations showed that, at a $5 \%$ probability, the variances can be considered homogeneous, since the calculated values of the statistics were 0.40 and 0.41 , respectively, and the critical value of 2.59 , ie, it is accepted that there is no statistical difference between the variances analyzed.

The temporal variation of annual monthly rainfall values observed and simulated for the station of Bagé/RS/Brazil for observed and simulated were 126.3 $\mathrm{mm}$ (1991 to 2012) and $127.9 \mathrm{~mm}$ (2013 to 2034), respectively (Figures $2 \mathrm{a}, 2 \mathrm{~b}$ ).

The SPI presents a slight decrease in the index over time, suggesting increase in the number of negative values indicative of drought, behavior not 
observed in the simulated series (Figure 3a, 3b). Results also show the SPI values between -1.50 to -1.99 and those smaller than -2.00 , ranked by Fernandes et al. (2010) as extreme and severe drought, respectively, with a larger number of events of severe and extreme drought in the series observed compared to the simulated series. In observed series, from 1991 to 2012, there were 9 events and 11 severe drought of extreme drought, while for the simulated series, 6 of 6 severe drought and extreme drought.

a)

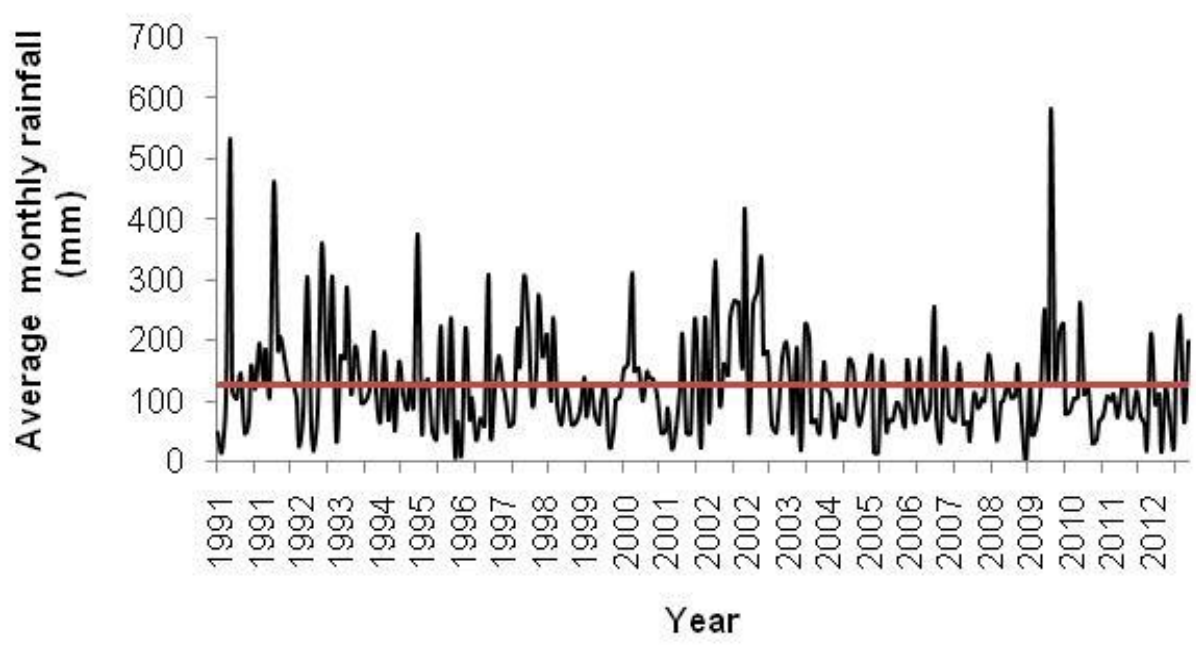

-observed series -Mean

b)

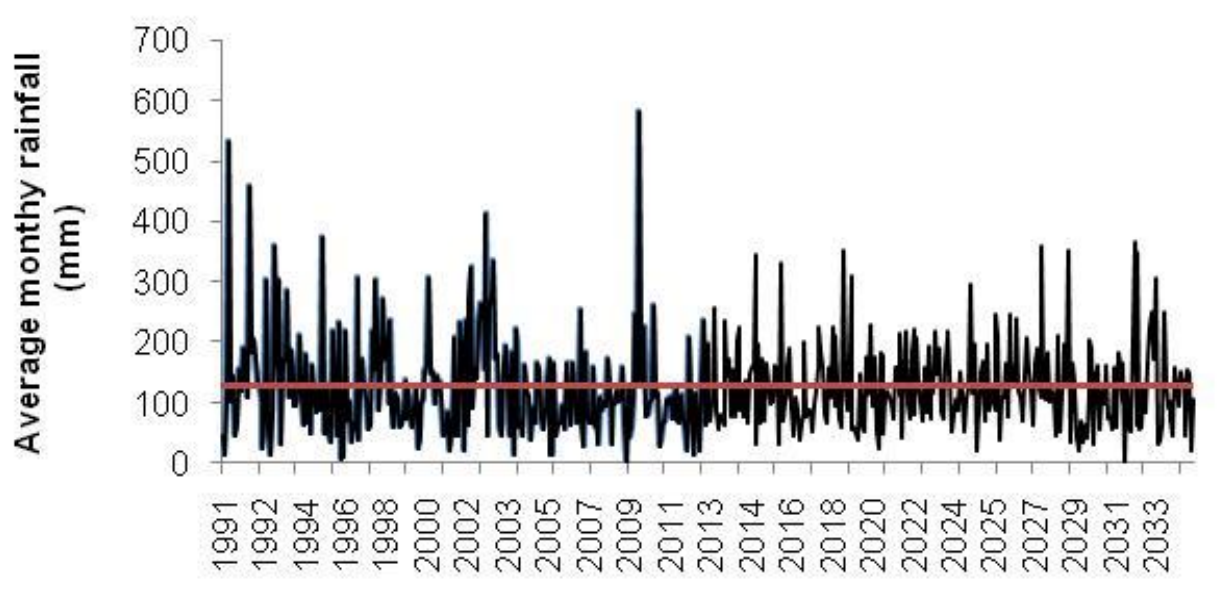

Year

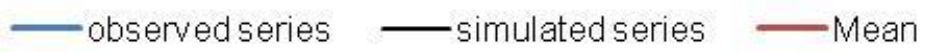

Figure 2 - Temporal variation of the values of annual monthly rainfall observed $(1991-2012$ - mean $=126.3 \mathrm{~mm})(\mathrm{a})$; and simulated (2013 a 2034 to $127.9 \mathrm{~mm}$ ) (b), for the season Bagé/RS/Brazil

In simulated series was observed the prediction of severe drought for the month of March 2015 $(\mathrm{SPI}=-1.57)$ and $2016(\mathrm{SPI}=-1.64)$ in October 2019 $(\mathrm{SPI}=-1.93)$ and $2021(\mathrm{SPI}=-1.76)$ and November $2034(\mathrm{SPI}=-1.66)$. Regarding to extreme drought was observed prediction of events in September 2020 $(\mathrm{SPI}=-2.10)$, February $2025(\mathrm{SPI}=-2.01)$, October
2029 (SPI $=-2.77$ ), June $2030($ SPI $=-2.28)$ and November 2031 (SPI = -2.69). It should be highlighted the year 2033, with an expected sequence of months with occurrence of severe drought (SPI $=-1.59$ ), extreme drought $(\mathrm{SPI}=-1.93)$ and weak drought $(\mathrm{SPI}=-0.93)$ in May, June and July, respectively. 
a)

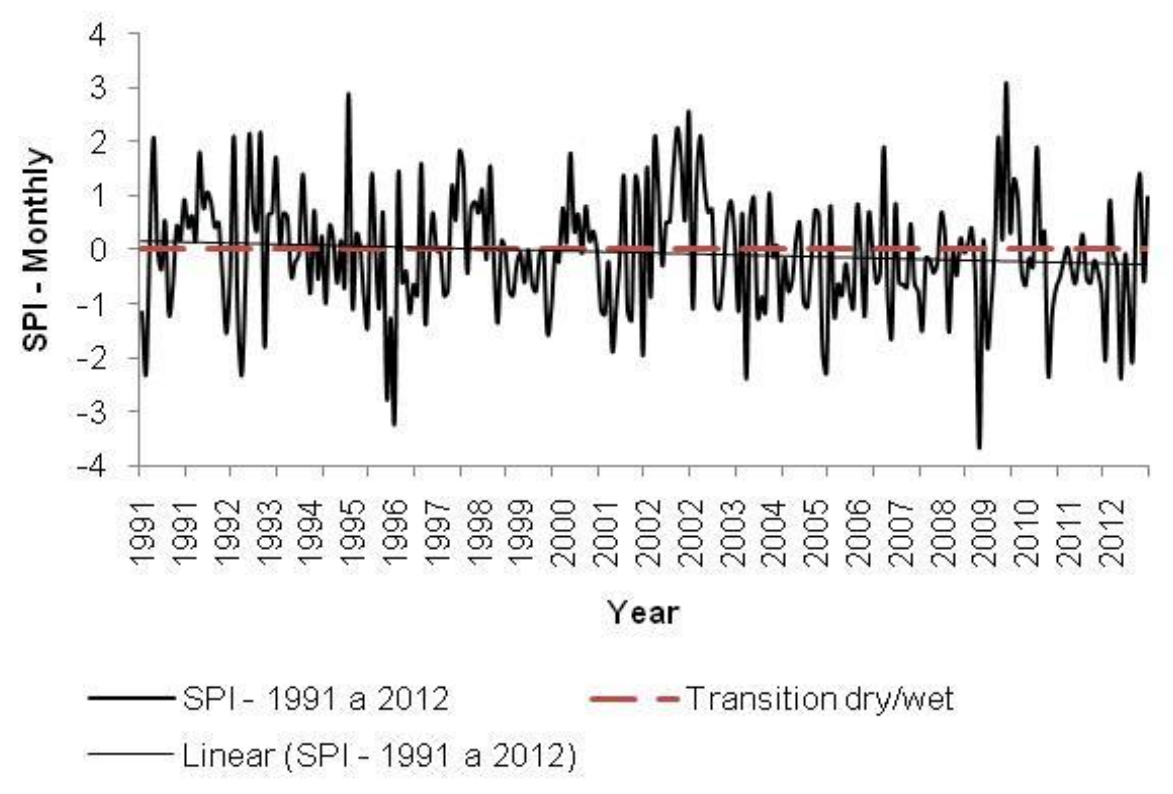

b)

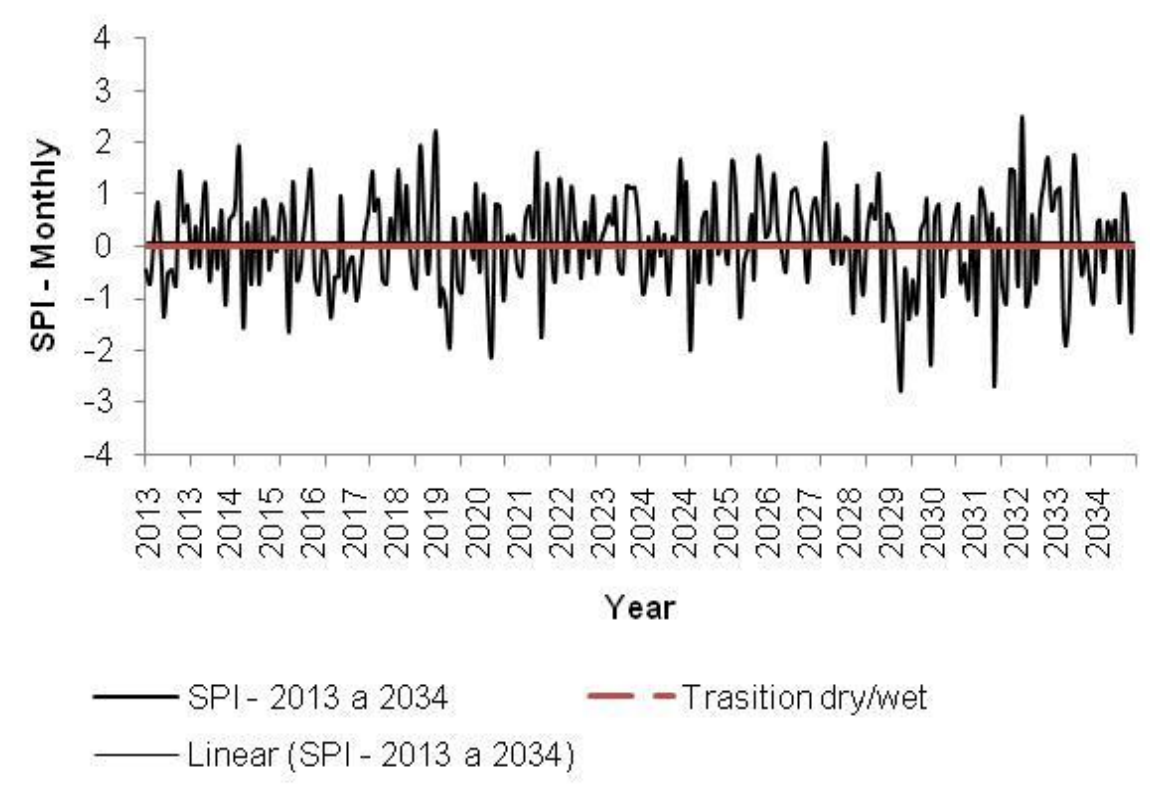

Figure 3 - Standardized Precipitation Index (SPI) observed (a) and simulated (b) for the city of Bagé/RS/Brazil, in the period 1991-2034.

\section{Conclusions}

In studies related to persistence of the dry period, the Markov model, in this work, adequately represented the observed data series of the city of Bagé/RS/Brazil, concluding that it can be used to simulate continuous periods of drought. The same conclusion is true for continuous wet periods.

The transition probabilities of dry/wet and wet/dry states of simulated series showed greater deviation related to observed one, however, without prejudice to the simulated series.
Due to the values obtained by simulated Standardized Precipitation Index series, compared to that observed, there was an underestimation of the number of events classified as extreme and severe drought.

\section{References}

Abramowitz M, Stegun IA (1965) Handbook of mathematical functions with formulas, graphs, and mathematical tables, New York: Dover. 1046p. 
Andrade ARS, Paixão FJR, Azevedo CAV, Gouveia, JPG, Oliveira Júnior JAS (2008) Estudo do comportamento de períodos secos e chuvosos no município de Garanhuns, PE, para fins de planejamento agrícola. Revista Brasileira de Tecnologia Aplicada nas Ciências Agrárias 1(1):55-61.

Andrade Júnior AS, Frizzone JA, Sentelhas PC (2001) Simulação da precipitação diária para Parnaíba e Teresina, PI, em planilha eletrônica. Revista Brasileira de Engenharia Agrícola e Ambiental 5(2):271-278.

Araújo WS, Sousa FAZ, Brito JIB, Lima LM (2012) Aplicação do modelo estocástico Cadeia de Markov a dados diários de precipitação dos Estados da Bahia e Sergipe. Revista Brasileira de Geografia Física 5(3):509-523.

Azevedo PV, Leitão MMVBR (1990) Aplicação de processos em cadeia de Markov as precipitações diárias no Estado da Paraíba. Revista Brasileira de Meteorologia 5(1):389-402.

Berlato MA, Cordeiro APA (2005) V climática e agricultura do Rio Grande do Sul. In: Nascimento CAM, Silveira Filho IL, Berton AL, Berlato MA, Melo IB, Cordeiro APA, Porto RO, Ferreira TN, Almeida AC, Denardin JE, Kochhann RA, Everling P. As estiagens e as perdas na agricultura: fenômeno natural ou imprevidência? Federacite, p.17-42.

Blain G, Pezzopane JRM, Pezzopane JEM, Bonomo R (2010) Índice padronizado de precipitação aplicado às condições de seca no Estado do Espírito Santo. Revista Brasileira de Engenharia Agrícola e Ambiental 14(10):1067-1073.

Blain GC, Picoli MCA, Lulu J (2009) Análises estatísticas das tendências de elevação nas séries anuais de temperatura mínima do ar no Estado de São Paulo. Bragantia 68(3):807-815.

Breinl K, Turkington T, Stowasser M (2013) Stochastic generation of multi-site daily precipitation for applications in risk management. Journal of Hydrology 498(19):23-35.

Cargnelutti Filho A, Matzenauer R, Maluf JRT, Radin B (2010) Modelo harmônico para a estimativa da temperatura do ar média mensal em diferentes locais do Estado do Rio Grande do Sul. Ciência Rural 40(9):1888-1896.

Carvalho AL, Souza JL, Lyra GB, Porfirio ACS (2013) Ocorrência de períodos secos na região de rio Largo, Alagoas. Revista Brasileira de Meteorologia 28(2):173-180.
Damé RCF, Teixeira CFA, Terra VSS (2008) Comparação de diferentes metodologias para estimativa de curvas intensidade-duração-frequência para PelotasRS. Engenharia Agrícola 28(2):244-255.

Dereczynski CP, Oliveira JS, Machado CO (2009) Climatologia da precipitação no Município do Rio de Janeiro. Revista Brasileira de Meteorologia 24(1):24-38.

Detzel DHM, Mine MRM (2011) Modelagem de quantidades precipitadas em escala diária: uma análise comparativa. Revista Brasileira de Recursos Hídricos 16(2):101-110.

Fernandes DS, Heinemann AB, Paz RLFE, Amorim AO (2010) Desempenho de índices quantitativos de seca na estimativa da produtividade de arroz de terras altas. Pesquisa Agropecuária Brasileira 45(8):771-779.

Hayes MJ, Svoboda MD, Wilhite DA, Vanyarkho OV (1999) Monitoring the 1996 drought index using the standardized precipitation index. Bulletin of the American Meteorological Society 80 (3):429-438.

Mckee TB, Doesken NJ, Kleist J (1993) The relationship of drought frequency and duration to times scale. Boston. Anais... Conference on Applied Climatology 8.

Mehrotra R, Srikanthan R, Sharma A (2006) A comparison of three stochastic multi-site precipitation occurrence generators. Journal of Hydrology 331(12):280-292.

Salas JD, Delleur JW, Yevjevich V, Lane WL (1980) Applied modelling of hydrologic time series. Water Resources Publication, 484p.

Sansigolo CA (2004) Análise comparativa do desempenho dos índices de seca de Palmer (PDSI) e da precipitação normalizada (SPI) em Piracicaba, SP (1917-2001). Revista Brasileira de Meteorologia 19(1):237-242.

Stern RD, Coe R (1984) A model fitting analysis of daily rainfall data. Journal of the Royal Statistical Society $147(1): 1-34$

Thom HCS (1966) Some methods of climatological analysis. World Meteorological Organization, Geneva. $53 p$.

Wilks DS (2006) Theoretical probability distributions. In: Statistical methods in the atmospheric sciences, Academic Press, p.102-104. 